\title{
MINAT MAHASISWA ANGGOTA INTERNATIONAL ASSOCIATION OF STUDENT IN AGRICULTURAL AND RELATED SCIENCES (IAAS) INDONESIA UNTUK BEKERJA DI SEKTOR PERTANIAN
}

\author{
STUDENT INTEREST OF INTERNATIONAL ASSOCIANTION OF STUDENT IN \\ AGRICULTURAL AND RELATED SCIENCES (IAAS) INDONESIA MEMBERS TO \\ WORK IN AGRICULTURE FIELD
}

\author{
Hasna Putri*, Rani Andriani Budikusumo \\ Universitas Padjajaran \\ *Email: hasnaputri07@gmail.com \\ (Diterima 11-02-2020; Disetujui 10-04-2020)
}

\begin{abstract}
ABSTRAK
Sektor pertanian merupakan sektor yang banyak menyerap tenaga kerja di Indonesia, namun terdapat permasalahan pada ketenagakerjaaan di sektor pertanian, yaitu tingginya jumlah usia tua dan rendahnya tingkat pendidikan tenaga kerja. Rendahnya minat terhadap pertanian menjadi salah satu penyebab hal ini tu terjadi. IAAS Indonesia adalah organisasi yang menjadi wadah untuk mahasiswa untuk mengeluarkan aspirasi mereka untuk membangun sektor pertanian. Tujuan dari penelitian untuk menganalisis (1) Minat bekerja di sektor pertanian pada mahasiswa anggota IAAS Indonesia, dan (2) Hubungan antara faktor pendorong minat dengan minat mahasiswa anggota IAAS Indonesia untuk bekerja di sektor pertanian. Penelitian ini merupakan penelitian kuantitatif dengan teknik survey deskriptif. Penelitian dilakukan kepada 88 mahasiswa melalui penggunaan rumus slovin. Analisis yang digunakan pada penelitian ini untuk mengukur minat mahasiswa dengan menggunakan skala likert dan korelasi rank spearman untuk menguji hubungan faktor pendorong minat. Hasil penelitian menunjukan bahwa minat untuk bekerja di sektor pertanian pada mahasiswa anggota IAAS Indonesia bisa dibilang tinggi. Faktor yang berhubungan dengan minat mahasiswa untuk bekerja di sektor pertanian adalah pribadi mahasiswa, faktor emosional, motif ekonomi dan kondisi pekerjaan.
\end{abstract}

Kata kunci: Minat bekerja, Generasi Muda, IAAS

\section{ABSTRACT}

Agriculture sector is a sector that take a lot of labor in Indonesia. There is a promblem with employment in agriculture sector, the high amount of old age labor and labor with low education. The lack of interest with agriculture from young generation is one of the causes that problem is happened. IAAS Indonesia is an organization that can be a place for young generation to give their aspiration about agriculture in Indonesia. The purpose of the study was to analyze (1) the interst to work in agriculture field of student as a part of IAAS Indonesia and (2) a correlations between interest factor and the interest to work in agricultural field. Data is collected by using questionnaires with a member of IAAS Indonesia. This research is a quantitative study with descriptive survey techniques. The study was conducted to 88 students through the use of the Slovin formula.The result show that an interest to work in agriculture field for student of member IAAS Indonesia is in high category and factor which connect with student interest are personality of the student, emotional factor, economics motive and condition of the work.

Keywords: interest of working, young generation, IAAS 


\section{PENDAHULUAN}

Pertanian merupakan sektor yang penting untuk pembangunan negara Indonesia. Sektor pertanian berperan pada perekonomian negara dalam menyerap tenaga kerja, sumber pertumbuhan ekonomi, pemenuhan kebutuhan pangan, penyedia bahan mentah untuk industri, dan penyumbang devisa. Selain itu, sektor pertanian juga dapat membantu beberapa sektor diluar pertanian dalam perekonomian nasional (Badan Pusat Statistik, 2018)

Penyerapan tenaga kerja pertanian jumlahnya cukup besar, yaitu mencapai 36,91 juta orang pada Februari 2018, yang berarti sebesar $30,46 \%$ tenaga kerja di Indonesia bekerja dalam bidang pertanian (Kementerian Pertanian, 2018). Namun terdapat permasalahan dalam ketenaga kerjaan di sektor pertanian, yaitu terjadi perubahaan struktur demografi dimana petani yang berusia tua jumlahnya semakin banyak. Dalam waktu satu tahun jumlah tenaga kerja usia tua (di atas 55 tahun) sudah bertambah, pada tahun 2017 terdapat 27,5\% petani usia tua dan meningkat sebanyak $0.25 \%$ pada tahun berikutnya. Peristiwa menuanya petani dan semakin rendahnya minat tenaga kerja muda di dalam sektor pertanian membuat munculnya masalah klasik dalam ketenagaan kerjaan pertanian, yaitu rendahnya rata-rata tingkat pendidikan tenaga kerja pertanian. (Susilowati, 2016).

Rendahnya pendidikan tenaga kerja di pertanian juga menjadi masalah, tenaga kerja dengan lulusan sekolah dasar mendominasi tenaga kerja yang bekerja di dalam sektor pertanian. Sedangkan persentase terkecil ada pada lulusan universitas ataupun D-IV (Kementerian Pertanian, 2018). Melihat data yang ada, maka hal itu membuat pertanyaan bahwa dimanakah keberadaan lulusan pertanian yang menempuh pendidikan cukup tinggi padahal generasi muda merupakan harapan bagi negara Indonesia untuk mewujudkan cita-cita bangsa dan juga mempertahankan kedaulatan bangsa, mulai dari yang masih berstatus sebagai pelajar, mahasiswa hingga yang sudah menyelesaikan pendidikan. Generasi muda dapat dijadikan agent of change untuk sektor pertanian

Pada saat ini banyak sarjana pertanian yang memilih pekerjaan tidak sesuai dengan jurusan yang mereka pilih saat berkuliah; atau dengan kata lain bekerja diluar sektor pertanian. Data Ditjen Dikti Kementerian Pendidikan Nasional menunjukan bahwa jumlah sarjana pertanian yang didalamnya 
termaksud dengan sarjana peternakan dan perikanan mencapai $3,32 \%$ dari seluruh sarjana yang ada di Indonesia. Dengan itu, maka lulusan pertanian bisa mencapai angka tiga ratus ribu, jika banyak lulusan pertanian yang bekerja di sektor pertanian, hal ini bisa menjadi harapan untuk Indonesia untuk mencetak generasi pertanian yang dapat memajukan pertanian Indonesia. Hal ini disebabkan karena rendahnya minat tenaga kerja baru yang ingin bekerja di sektor pertanian.

Minat adalah suatu bagian dari mental yang mengandung suatu campuran perasaan, harapan, prinsip, prasangka, rasa takut atau hal lainnya yang mengarahkan individu kepada pemikiran tertentu. Dalam kata lain minat adalah kecendrungan yang besar terhadap suatu hal (Syah, 2005). Dalam pembentukan minat, tentunya ada faktorfaktor yang mempengaruhi minat itu sendiri. Faktor minat memiliki peran yang penting, minat seseorang terhadap suatu objek, pekerjaan, orang, benda dan beberapa permasalahaan yang menyangkut tentang dirinya timbul karena ada faktor yang berpengaruh terhadap objek yang diamati (Suharyat, 2009). Menurut Agus Sujanto, terdapat dua faktor yang dapat mempengaruhi terbentuknya minat, yaitu faktor internal dan eksternal. Faktor internal adalah faktor yang berasal dari pribadi itu sendiri sedangkan faktor eksternal adalah faktor yang berasal dari luar seperti lingkungan keluarga, lingkungan sekolah, dan lingkungan masyarakat ${ }^{1}$. Adapun beberapa faktor yang mempengaruhi minat kerja seseorang menurut Yuwono (2001), yaitu kondisi pekerjaan, sistem pendukung, pribadi pekerjaan

Berdasarkan beberapa sumber yang ada, penelitian ini mengambil kesimpulan bahwa terdapat faktor-faktor yang berpeluang untuk mendorong minat mahasiswa untuk bekerja di sektor pertanian. Faktor tersebut digolongkan menjadi 2 faktor, yaitu faktor internal dan faktor eksternal. Faktor internal yang berhubungan dengan minat mahasiswa untuk bekerja pada sektor pertanian diantaranya adalah faktor emosional yang dimiliki pekerja, dan pribadi pekerja.

Faktor eksternal yang berhubungan dengan minat mahasiswa untuk bekerja di sektor pertanian diantaranya yaitu: Motif sosial, motif ekonomi, kondisi pekerjaan, dan sistem pendukung.

Mahasiswa yang sedang menjalankan studinya di kampus bukan hanya berkegiatan di dalam hal akademis, tapi sebagian mahasiswa juga mengikuti

\footnotetext{
${ }^{1}$ Yasin Setiawan, op.cit.,h. 12
} 
kegiatan non-akademis. Salah satu kegiatan non-akademis yang diikuti adalah berorganisasi. Organisasi adalah penyatuan dari berbagai kegiatan yang saling berkaitan antara setiap anggota didalamnya secara tersusun dan mempunyai tujuan yang sama. Terdapat dua alasan pembentukan organisasi, yaitu (1) alasan social, dan (2) Alasan material. Manusia melaksanakan kegiatan organisasi berdasarkan alasan-alasan material. Dengan mengikuti organisasi, manusia dapat mendapatkan tiga hal yang tidak mungkin didapatkan sendiri, diantaranya adalah memperbesar kemampuan, menghemat waktu dan mengakumulasi pengetahuan (Winordi, 2003).

International Association of Students in Agriculture and Related Sciences (IAAS) adalah organisasi untuk seluruh mahasiswa pertanian dan ilmu lain yang terkait di dunia. IAAS dapat menjadi tempat bagi para mahasiswa pertanian untuk mengeluarkan aspirasi mereka melalui berbagai macam kegiatan di bidang pertanian.

Menjadi bagian dari anggota IAAS bisa menjadikan mahasiswa tersebut mempelajari banyak hal terkait dengan bidang pertanian. Ilmu dan pengalaman yang didapatkan mengenai pertanian maka diharapkan dapat meningkatkan minat bekerja di sektor pertanian bagi mahasiswa anggota IAAS. Berdasarkan permasalahan yang sudah dipaparkan, maka penulis tertarik melakukan penelitian mengenai bagaimana minat mahasiswa anggota IAAS Indonesia untuk bekerja di sektor pertanian, dan faktor apa saja yang dapat menimbulkan minat untuk bekerja di sektor pertanian.

\section{METODE PENELITIAN}

Tempat penelitian yang dipilih yaitu Organisasi IAAS yang berlokasi di 8 kampus, yaitu IPB, UNPAD, UNIBRAW, UGM, UNS, UNDIP, ULM dan UNRAM. Desain penelitian yang digunakan adalah kuantitatif. Sampel penelitian ini yaitu para mahasiswa anggota IAAS Indonesia. Ukuran sampel sebanyak 88 orang menggunakan rumus slovin.

Variabel yang diteliti dalam penelitian ini adalah sebagai berikut:

1. Minat mahasiswa untuk bekerja di sektor pertanian pada mahasiswa anggota IAAS Indonesia dengan mengukur empat indikator minat, diantaranya rasa senang, keterlibatan, keinginan dan semangat.

2. Minat yang mendorong minat mahasiswa untuk bekerja di sektor pertanian yang dibagi menjadi dua, 
yaitu faktor internal yang terdiri atas pribadi mahasiswa dan faktor emosional serta faktor eksternal yang terdiri atas motif sosial, motif ekonomi, kondsi pekerjaan dan sistem pendukung.

Penelitian ini memakai skala likert dengan skor tertinggi pada setiap pertanyaannya adalah 5 dan skor terendah adalah 1. Dengan jumlah responden sebanyak 88 orang dan pertanyaan sejumlah 12 pertanyaan, maka skor terendah bernilai 1.056 dan skor tertinggi bernilai 5.280 sehingga rentang untuk hasil penelitian adalah 3.520. Dengan jumlah kelas sebanyak 3 kelas, maka panjang interval kelas (p) adalah sebagai berikut:
a. $1.760-2.933,33=$ Minat Rendah
b. $2.934,33-4 \cdot 107,70=$ Minat Sedang
c. $4.108 .7,1-5.280=$ Minat Tinggi

Rentang skor ini merupakan hasil kesimpulan untuk variabel minat mahasiswa anggota IAAS Indonesia untuk bekerja di sektor pertanian.

Analisis statistika non parametrik kolerasi Rank Spearman digunakan untuk menganalisis terdapat hubungan antara faktor-faktor timbulnya minat bekerja dengan minat mahasiswa bekerja.
Kolerasi spearman dipakai untuk data berskala ordinal. Rumus korelasi Rank Spearman menurut Siegel (1994):

$$
\rho=1-\frac{6 \sum d i^{2}}{N^{3}-N}
$$

Kekuatan hubungan antara variabel yang akan diuji dapat dinyatakan melalui lima korelasi, diantaranya adalah:
a. $0,00-0,19=$ Sangat Lemah
b. $0,20-0,39=$ Lemah
c. $0,40-0,59=$ Sedang
d. $0,60-0,79=$ Kuat
e. $0,80-1,00=$ Sangat Kuat

\section{HASIL DAN PEMBAHASAN}

Minat merupakan perpaduan antara keinginan dan kemauan seseorang sehingga dapat berkembang bila diiringi dengan motivasi (Tampubolon, 1991). Terdapat beberapa indikator yang dapat dipakai untuk menghitung tingkat minat pada mahasiswa anggota IAAS Indonesia, penelitian ini menggunakan indikator diantaranya adalah 1) perasaan senang 2) keterlibatan 3) semangat, dan 4) keinginan.

Hasil pengukuran scoring variabel minat mahasiswa untuk bekerja di sektor pertanian tersaji pada Tabel 1. 
Tabel 1. Total Skor Minat Bekerja di Sektor Pertanian pada Mahasiswa Anggota IAAS Indonesia

\begin{tabular}{lccc}
\hline \multicolumn{1}{c}{ Indikator } & Skor & Total Skor & Interperasi \\
\hline $\begin{array}{l}\text { Perasaan senang mahasiswa pada kegiatan yang bersangkutan } \\
\text { dengan pertanian }\end{array}$ & 1.779 & 2.200 & Tinggi \\
$\begin{array}{l}\text { Keterlibatan mahasiswa dalam kegiatan pertanian } \\
\begin{array}{l}\text { Keinginan mahasiswa untuk mengikuti kegiatan yang berkaitan } \\
\text { dengan pertanian }\end{array}\end{array}$ & 532 & 880 & Sedang \\
$\begin{array}{l}\text { Semangat mahasiswa dalam mengikuti kegiatan yang berkaitan } \\
\text { dengan pertanian }\end{array}$ & 1.045 & 1.320 & Tinggi \\
\hline Jumlah & & & $\mathbf{4 . 0 7 4}$ \\
\hline
\end{tabular}

Berdasarkan hasil analisis minat mahasiswa bekerja di sektor pertanian empat indikator maka dapat disimpulkan bahwa indeks tingkat minat bekerja di sektor pertanian pada mahasiswa anggota IAAS Indonesia adalah tinggi dengan persentase sebesar $77.16 \%$. Hasil perhitungan dari skor tingat minat mahasiswa untuk bekerja di sektor pertanian pada mahasiswa anggota IAAS Indonesia adalah sebagai berikut.

Skor tingkat minat bekerja di sektor pertanian

$$
\begin{aligned}
\text { Tingkat minat } & =\frac{4074}{5280} \times 100 \% \\
& =77.16 \%
\end{aligned}
$$

Minat yang tinggi pada mahasiswa anggota IAAS sejalan dengan pandangan mahasiswa anggota IAAS Indonesia terhadap pertanian. Mahasiswa berpikir bahwa sektor pertanian adalah suatu pekerjaan yang mulia dan mempunyai prospek kerja yang banyak. Kebanyakan mahasiswa berminat untuk bekerja di bagian subsistem penunjang ataupun pemasaran seperti menjadi dosen, pegawai negeri sipil, penyuluh, supplier dan pekerjaan lainnya.

Selain hasil dari minat yang tinggi, juga terdapat mahasiswa yang tidak berminat untuk bekerja di sektor pertanian. Hal ini disebabkan karena mereka memilih jurusan pertanian untuk sekedar masuk ke perguruan negeri tinggi dan pilihan orang tua. Beberapa mahasiswa juga sudah mempunyai pekerjaan yang mereka impikan, yaitu pekerjaan di luar sektor pertanian. Kesan kotor dan juga panas bagi beberapa mahasiswa juga menjadikan beeberapa mahasiswa tidak tertarik untuk bekerja di sektor pertanian, maka dari itu tingkat keterlibatan mahasiswa hasil skornya paling kecil diantara skor indikator lainnya.

Hasil minat bekerja di sektor pertanian pada mahasiswa IAAS Indonesia yang sudah didapatkan, bertolak belakang dengan data dari Badan Pusat Statistika (2018) yang menjelaskan bahwa tenaga kerja dengan lulusan sekolah dasar mendominasi tenaga kerja 
yang bekerja di dalam sektor pertanian. Sedangkan persentase terkecil ada pada lulusan universitas ataupun D-IV dengan perolehan angka sebesar 0,45\%. Minat untuk bekerja di sektor pertanian pada mahasiswa bisa jadi bukan merupakan penyebab utama dari kurangnya tenaga kerja yang kompetan dan berpendidikan tinggi pada sektor pertanian.

Hasil korelasi rank spearman menunjukan bahwa minat bekerja di sektor pertanian pada mahasiswa anggota IAAS Indonesia dipengaruhi oleh pribadi mahasiswa, faktor emosional, motif ekonomi, dan kondisi pekerjaan karena signifikansi dari hasil korelasi tidak lebih dari 0,05 dan hubungan yang dimiliki adalah hubungan searah dimana hal ini menandakan semakin tinggi pandangan mahasiswa terhadap pertanian, rasa bangga mahasiswa, pendapatan yang didapatkan jika bekerja di sektor pertanian dan kondisi yang nyaman untuk bekerja di sektor pertanian, maka semakin tinggi pula minat mahasiswa untuk bekerja di sektor pertanian.

Motif sosial dan sistem pendukung tidak memiliki hubungan dengan minat mahasiswa untuk bekerja di sektor pertanian. Pendapat terhadap orang sekitar mahasiswa terhadap pekerjaan mereka di sektor pertanian dan juga sistem pendukung yang ada di sektor pertanian tidak menjadi faktor yang mendorong mahasiswa unntuk bekerja di sektor pertanian. Hal ini disebabkan karena sistem pendukung yang ada dilahan tidak berhubungan dengan subsistem penunjang, dimana subsistem ini dipilih oleh mayoritas mahasiswa sebagai pilihan kerjanya. Hasil korelasi tersaji pada Tabel 3.

Tabel 1. Hasil Korelasi Rank Spearman

\begin{tabular}{lcc}
\hline Faktor & $\begin{array}{l}\text { Koefisien } \\
\text { Korelasi }\end{array}$ & Signifikansi \\
\hline Pribadi Mahasiswa & 0,516 & $0.00^{\mathrm{S}}$ \\
Faktor Emosional & 0,310 & $0.03^{\mathrm{S}}$ \\
Motif Sosial & 0,289 & $0.00^{\mathrm{TS}}$ \\
Motif Ekonomi & 0,171 & $0.11^{\mathrm{S}}$ \\
Kondisi Pekerjaan & 0,617 & $0.00^{\mathrm{S}}$ \\
Sistem Pendukung & 0,289 & $0.06^{\mathrm{TS}}$ \\
\hline
\end{tabular}

Ket: S: Signifikan, TS: Tidak Signifikan

\section{KESIMPULAN DAN SARAN}

\section{Kesimpulan}

1. Mahasiswa IAAS Indonesia memiliki minat yang tinggi untuk bekerja di sektor pertanian. Minat yang tinggi ini didasari oleh empat indikator, yaitu (1) Perasaan senang dengan kegiatan yang bersangkutan dengan pertanian, (2) Keterlibatan mahasiswa dalam mengikuti kegiatan yang bersangkutan dengan pertanian, (3) Keinginan mahasiswa untuk melakukan kegiatan yang bersangkutan dengan pertanian, dan (4) Semangat mahasiswa dalam 
mengikuti kegiatan yang berkaitan dengan pertanian.

2. Minat bekerja di sektor pertanian pada mahasiswa anggota IAAS Indonesia dipengaruhi oleh pribadi mahasiswa, faktor emosional, motif ekonomi, dan kondisi pekerjaan. Motif sosial dan sistem pendukung tidak memiliki hubungan dengan minat mahasiswa untuk bekerja di sektor pertanian.

\section{Saran}

1. Meningkatkan kegiatan budidaya di lapangan dengan tekonologi yang sudah maju agar mahasiswa dapat merubah pandangan mereka terhadap lahan yang dikatakan panas dan kotor.

2. Menambahkan kegiatan workshop dan pelatihan di lahan pada program kerja yang ada pada organisasi IAAS, sehingga mahasiswa bisa lebih mengetahui lebih dalam keadaan yang ada di lahan dan mulai mencoba merasa nyaman dengan kondisi lahan pertanian.
3. Merekomendasikan mahasiswa baru untuk mengikuti organisasi pertanian yang ada di kampus untuk mendukung mata kuliah yang diikutinya dan membentuk minat untuk bekerja di sektor pertanian.

4. Mengarahkan dan membantu mahasiswa untuk mencari serta mendapatkan pekerjaan di sektor pertanian setelah lulus dari perguruan tinggi.

\section{DAFTAR PUSTAKA}

Badan Pusat Statistik. (2018). Hasil survei pertanian antar sensus (SUTAS) 2018.

Kementrian pertanian. (2018). Statistik Ketenagakerjaan Sektor Pertanian Februari 2018.

Siegel, S. (1994). Statistik Nonparametrik Untuk Ilmu-Ilmu Sosial. Jakarta: Gramedia Pustaka Utama.

Suharyat, Y. (2009). Hubungan antara sikap, minat dan perilaku manusia. Jurnal Region, 1(3): 1-19.

Syah, M. (2005). Psikologi Belajar. Jakarta: Raja Grafindo Persada.

Tampubolon, (1991). Mengembangkan Minat dan Kebiasaan Membaca. Bandung: Angkasa.

Winordi, J. (2003). Teori Organisasi dan Pengorganisasian. Jakarta: Raja Grafindo Persada. 